\section{The Chronic Development of Rio Grande Gummosis in Florida Grapefruit}

\author{
Charles Arthur Powell ${ }^{1}$ \\ University of Florida, IFAS Indian River Research and Education Center, \\ 2199 South Rock Road, Fort Pierce, FL 34945-3138
}

Rio Grande Gummosis (RGG) is a serious disorder of grapefruit in the Caribbean Basin (Childs, 1978). It has also been referred to as Florida gummosis and ferment gum disease (in California) (Calavan, 1961). The disorder has distinct symptoms that distinguish it from other declines of citrus, including citrus blight, citrus tristeza decline, and citrus root weevil decline. RGG symptoms begin with slight cracking of the lower trunk bark above the graft union with a yellow gum exuding from the cracks. The gum is water-soluble and may not be visible during the summer rainy season. In the secondary phase of the disorder, trees develop a burned, charcoallike appearance around the cracks and gumming areas of the trunk. In the third phase of the disorder, the bark-splitting, gumming, and charcoal-like symptoms are also present on the primary and sometimes secondary scaffold branches. In the final stage, trees have bark loss and foliar decline. These symptoms are distinct from other citrus declines. RGG often occurs in combination with other citrus declines.

The cause of RGG is not known. RGG has been attributed to fungi isolated from lesions (Davis, 1988), high chloride in irrigation water (Childs, 1978), and undetermined abiotic etiologies based on spatial patterns (Sonoda and Pelosi, 1990) and disease progress curves (Sonoda et al., 1992). Most recently, RGG has been associated with a psorosis-like agent (Powell et al., 1998), but long-term studies testing the relationship of this agent with RGG are not yet complete.

RGG has been considered a problem limited to older grapefruit trees (older than 20 years), but younger trees may also develop symptoms (Hebb and Sonoda, 1992). This study was conducted to examine young (1 to 12 years), medium-aged ( 10 to 21 years), and old (20 to 31 years) grapefruit groves in three Florida counties over a period of 12 years to determine when RGG symptoms first appear, the progression of symptoms over time, and the effect of location and tree age on symptom severity.

Eighteen Ruby Red grapefruit (Citrus paradisi Macf.) groves on the east coast of

\footnotetext{
Received for publication 6 May 2008. Accepted for publication 9 July 2008.

${ }^{1}$ To whom reprint requests should be addressed; e-mail CAPowell@ufl.edu.
}

Florida were selected. Six of the groves were in each of three counties: Martin, St. Lucie, and Indian River. Two of the groves in each county were 1 year old, 11 years old, or 21 years old when they were selected. Each spring for 12 years, 25 trees in each of four rows in each of the 18 groves were visually inspected and rated for symptoms of RGG. The rows were adjacent to each other and at least 10 trees or rows from the border of the grove. The same trees were rated each year. Ratings were made during periods of minimal rainfall (normally March and April) because heavy rainfall can dissolve the gum and make symptoms more difficult to read.

RGG symptoms were rated using a 1 to 5 visual scale. A rating of 1 indicated no RGG symptoms; a rating of 2 indicated some bark cracking on the lower trunk above the bud union with gum formation around the cracks; a rating of 3 indicated the presence of a burned, charcoal-like appearance on the lower trunk in addition to the cracking and gumming; a rating of 4 indicated Type 3 symptoms on the main trunk with gumming, bark-cracking, and a burnt appearance extending to the primary branches of the main trunk; and a rating of 5 indicated Type 4 symptoms with loss of bark and tree decline.

The data were subjected to analysis of variance using the SAS software program (SAS Institute, Cary, NC) with year, county, location, and age grouping as the main treatment effects (Table 1). Significant main treatment effects were separated by Duncan's multiple range test with $5 \%$ level of significance.

The main source of variation (percent of sum of squares) was among the three age groupings $(1,11$, or 21 years old trees at the no significant variation among the three counties or two locations within each county. RGG symptoms also had significant variation among the 12 years. The only significant interaction was year $\times$ age. Therefore, each year was analyzed independently with means of each age group separated within each year (Table 2).

During each of the 12 years of the study, young trees had less severe RGG symptoms than medium-aged trees, and medium-aged trees had less severe symptoms than old trees. Therefore, it appears that RGG severity is age-dependent, not site-dependent, in the onset of the experiment) (Table 1). There was grapefruit-growing region on the east coast of Florida.

RGG symptoms were never detected in trees that were younger than 6 years old. Initial symptoms (Type 1 ) occurred in $\approx 25 \%$ of the trees that were 10 years old (data not shown). By 20 years, $\approx 80 \%$ of trees had some degree of RGG. If individual trees with RGG were observed, symptoms never regressed but progressed at different rates in different trees. Therefore, RGG is a chronic disorder whose progression is affected by unknown factors.

This study presents three new pieces of information. First, it confirms the unpublished observation that RGG is a chronic disease. The data clearly indicate that the disease progresses over time. Second, this study indicates that severe symptoms (Type 4 or higher) did not occur in trees younger than 20 years old, but are fairly common in 30year-old trees. Third, initial symptoms attributed to the disorder can occur in trees as young as 6 years old.

RGG likely contributes to decline and reduced productivity of older grapefruit trees. However, many other sources of decline also existed in the groves monitored in this study. These included Citrus tristeza virus, Diaprepes root weevil feeding, and citrus blight-induced decline. Each of these declines are also chronic and their relative contributions (separately or in combination with RGG) to reduced productivity cannot be determined from this study. All the trees were from sources certified free of citrus psorosis, which can produce symptoms similar to RGG. At the conclusion of the experiment, five trees from each block were tested and shown to be negative for psorosis by polymerase chain reaction.

The cause of RGG remains unknown. It has been suggested that it may have an abiotic (Sonoda et al., 1992) or biotic (Powell et al., 1998) etiology. Because neither location within county nor county was a significant

Table 1. Analysis of variance of a 12-year study of 18 Florida grapefruit groves for the severity of Rio Grande Gummosis.

\begin{tabular}{lrc}
\hline Source & df & $\begin{array}{c}\text { Mean } \\
\text { square }\end{array}$ \\
\hline Year & 11 & $9.66^{* *}$ \\
County & 2 & 0.14 \\
Location & 1 & 0.02 \\
Age & 2 & $38.67^{* *}$ \\
Year $\times$ county & 22 & 0.09 \\
Year $\times$ location & 11 & 0.09 \\
Year $\times$ age & 22 & $0.34 *$ \\
County $\times$ location & 2 & 0.02 \\
County $\times$ age & 4 & 0.09 \\
Location $\times$ age & 2 & 0.03 \\
Year $\times$ county $\times$ location & 24 & 0.09 \\
Year $\times$ county $\times$ age & 48 & 0.07 \\
Year $\times$ location $\times$ age & 24 & 0.06 \\
County $\times$ location $\times$ age & 4 & 0.01 \\
Year $\times$ county $\times$ location $\times$ age & 44 & 0.82 \\
\hline Sources
\end{tabular}

${ }^{\text {z }}$ Sources of variation were 12 years (1992 to 2003), three counties (St Lucie, Martin, Indian River), two locations per county, and three age groups (trees in 1992 were 1 year old, 11 years old, or 21 years old). ${ }^{*}$ F-test significant at the 5\% level.

${ }^{* *}$ F-test significant at the $1 \%$ level. 
Table 2. Severity of Rio Grande Gummosis symptoms in grapefruit of different ages s.y. $^{\text {, }}$.

\begin{tabular}{lllllllllllll}
\hline & \multicolumn{10}{c}{ Year } \\
\cline { 2 - 11 } & 1992 & 1993 & 1994 & 1995 & 1996 & 1997 & 1998 & 1999 & 2000 & 2001 & 2002 & 2003 \\
\hline 1 & $1.0 \mathrm{a}$ & $1.0 \mathrm{a}$ & $1.0 \mathrm{a}$ & $1.0 \mathrm{a}$ & $1.0 \mathrm{a}$ & $1.1 \mathrm{a}$ & $1.2 \mathrm{a}$ & $1.4 \mathrm{a}$ & $1.4 \mathrm{a}$ & $1.6 \mathrm{a}$ & $1.7 \mathrm{a}$ & $1.6 \mathrm{a}$ \\
2 & $1.5 \mathrm{~b}$ & $1.5 \mathrm{~b}$ & $1.6 \mathrm{~b}$ & $1.7 \mathrm{~b}$ & $1.9 \mathrm{~b}$ & $2.0 \mathrm{~b}$ & $2.2 \mathrm{~b}$ & $2.2 \mathrm{~b}$ & $2.2 \mathrm{~b}$ & $2.4 \mathrm{~b}$ & $2.5 \mathrm{~b}$ & $2.7 \mathrm{~b}$ \\
3 & $2.4 \mathrm{c}$ & $2.5 \mathrm{c}$ & $2.7 \mathrm{c}$ & $2.7 \mathrm{c}$ & $2.9 \mathrm{c}$ & $3.1 \mathrm{c}$ & $3.2 \mathrm{c}$ & $3.3 \mathrm{c}$ & $3.3 \mathrm{c}$ & $3.4 \mathrm{c}$ & $3.6 \mathrm{c}$ & $3.6 \mathrm{c}$ \\
\hline
\end{tabular}

${ }^{2}$ Severity ratings were based on an annual visual observation: $1=$ no symptoms, $2=$ slight gumming and cracking of lower trunk bark above the graft union, $3=$ gumming and cracking of the lower trunk bark with a charcoal-like, burnt discoloration, 4 = Type 3 symptoms of the main trunk with gumming and cracking of the bark and burnt appearance of some primary branches on the main trunk, $5=$ Type 4 symptoms with loss of bark and tree decline.

${ }^{y}$ Numbers are the mean of 600 measurements: 25 trees in each of four rows in each of two locations in each of three counties. Means followed by different letters within a column are significantly different by Duncan's multiple range test (5\% level).

${ }^{x}$ Age grouping 1 = trees were planted in 1991; age grouping 2 = trees were 11 years old in 1992; age grouping 3 = trees were 21 years old in 1992.

factor in RGG, factors contributing to an abiotic etiology would need to be present at each sampling site. Likewise, a biotic agent would need to be transmitted to trees at similar rates at all the sites or, more likely, be present in the several nursery stock sources that provided the trees sampled in this study. There are many factors that may weaken grapefruit trees, both biotic and abiotic. These include virus infection, fungal infection, nutritional deficiencies, soil issues, water issues, and arthropod feeding. Perhaps any of these may contribute to RGG.

RGG remains an important contributor to grapefruit decline in Florida. Determining its cause and developing control procedures, although elusive, would positively impact grapefruit production in Florida.

\section{Literature Cited}

Calavan, E.C. 1961. Ferment gum disease (Rio Grande gummosis) of grapefruit. Calif. Citrog. 46:231-232.

Childs, J.F.L. 1978. Rio Grande gummosis disease of citrus trees. Part I. A brief review of the history and occurrence of Rio Grande gummosis. Plant Dis. Rep. 62:390-394.

Davis, R.M. 1988. Rio Grande gummosis, p. 67. In: Whiteside, J.O., S.M. Garnsey, and L.W. Timmer (eds.). Compendium of citrus diseases. American Phytopathological Society Press, St. Paul, MN.

Hebb, J.W. and R.M. Sonoda. 1992. For Florida grapefruit growers: Is gummosis becoming more of a problem? Citrus Industry 73:28-29.

Powell, C.A., R.R. Pelosi, R.M. Sonoda, and R.F. Lee. 1998. A psorosis-like agent prevalent in Florida's grapefruit groves and budwood sources. Plant Dis. 82:208-209.

Sonoda, R.M. and R.R. Pelosi. 1990. Fungi in Rio Grande gummosis lesions and patterns of gummosis-affected grapefruit trees in Indian River area groves. Proc. Fla. State Hort. Soc. 103:59-61.

Sonoda, R.M., R.R. Pelosi, and J.W. Hebb. 1992. Comparing Rio Grande gummosis and citrus blight incidence on grapefruit on Swingle citrumelo rootstock. Proc. Fla. State Hort. Soc. 105:28-32. 